\title{
Occurrence of Rabies in Post Exposure Vaccinated Cattle with Dog Bite Injury above the Neck Region
}

\author{
A.V. Bhosale, B.I. Awati, K.C. Mallinath, S. Isloor ${ }^{1}$,
}

B.G. Ravindra², G. Lunavat, K. Kavitha, A.G. Kharate ${ }^{3}$

10.18805/IJAR.B-4825

\begin{abstract}
Background: Investigated the fatality in bovines infected with rabies virus through dog bite, that have undergone the post bite therapy. The site of dog bite close to the brain was an important factor and reason behind the fatality.

Methods: The findings from cattle infected naturally with Rabies virus and vaccinated with post bite shots of anti-rabies vaccine were considered for the present study. The rabies cases i.e., 20 cases (out of total 58 cases reported) in bovines, from Bidar, Karnataka and Maharashtra border area, reported in last three years and bovines with site of dog bite specifically above neck region were considered. All the clinical samples were tested with direct fluorescent antibody test and reverse transcriptase polymerase chain reaction, amplifying the glycoprotein, $\mathrm{G}$ gene of rabies virus.

Result: In the diseased cattle, with history of dog bite above neck region, the average incubation period observed was 15 days in case of calves and 20 days in case of adults. The occurrence of clinical signs was seen in cattle undergoing the post bite vaccination. Fatality rate recorded was 100 per cent, despite having treated with post bite anti-rabies vaccine alone, without use of rabies antisera as a passive way of treating successfully in such cases. Rabies post bite vaccination is not protective, if the site of dog bite is above the neck region.

Key words: Cattle, Direct fluorescent antibody test, Post exposure vaccination, Rabies, Reverse transcriptase polymerase chain reaction.
\end{abstract}

\section{INTRODUCTION}

Rabies is a devastating and fatal zoonotic disease of human and animals (Jackson et al., 2007). Rabies is acute encephalitis caused by rabies virus (Mahadevan et al., 2016). Rabies virus is prototype species of the genus Lyssa virus, family Rhabdoviridae. Once clinical signs of Rabies set in 100 percent fatality is seen in animals as well as in humans, with few exceptions in humans, in the history of rabies (Willoughby et al., 2004; Madhusudana et al., 2002; Alvarez et al., 1994; Porras et al., 1976; Hattwick et al., 1972). Report of survival once clinical signs are manifested in animals, is not on record.

Rabies is endemic in developing countries of Africa and Asia. Globally canine rabies causes approximately 70,000 human deaths (Bedeković et al., 2018) and 8.6 billion USD economic losses annually (Hampson et al., 2015). It is endemic in India, with an estimated annual 20,000 human deaths (one-third of the global rabies burden). India accounts for the most deaths in Asia (59.9\% of human rabies deaths) and globally (36\% of human rabies deaths)(WHO 2018).

Information about the incidence of rabies in animal populations is not available in most of the developing countries. In cattle, no such specific numbers of deaths are placed on record, due to poor reporting, lack of awareness, surveillance and recording system. Rabies incidence in animals, particularly in cattle, is much higher than suspected and reported (Gill et al., 2019).

Dog bite is the main source of rabies virus in human and cattle. Though post-exposure prophylaxis (PEP) (Vaccination on $0,3,7,14$ and 28 days) is the only proven approach in preventing rabies deaths is however, not effective to the tune of cent per cent.
Department of Veterinary Microbiology, Veterinary College, Karnataka Veterinary, Animal and Fisheries Sciences University, Bidar-585 401, Karnataka, India.

${ }^{1}$ OIE Twinned Rabies Diagnostic Laboratory, Department of Veterinary Microbiology, Veterinary College, Karnataka Veterinary, Animal and Fisheries Sciences University, Hebbal, Bangalore-560 024, Karnataka, India.

2Department of Veterinary Medicine, Veterinary College, Karnataka Veterinary, Animal and Fisheries Sciences University, Bidar-585 401, Karnataka, India.

${ }^{3}$ Department of Veterinary Public Health, Veterinary College, Karnataka Veterinary, Animal and Fisheries Sciences University, Bidar-585 401, Karnataka, India.

Corresponding Author: A.V. Bhosale, Department of Veterinary Microbiology, Veterinary College, Karnataka Veterinary, Animal and Fisheries Sciences University, Bidar-585 401, Karnataka, India. Email: avbmic@gmail.com.

How to cite this article: Bhosale, A.V., Awati, B.I., Mallinath, K.C., Isloor, S., Ravindra, B.G., Lunavat, G., Kavitha, K. and Kharate, A.G. (2022). Occurrence of Rabies in Post Exposure Vaccinated Cattle with Dog Bite Injury above the Neck Region. Indian Journal of Animal Research. DOI: 10.18805/IJAR.B-4825.

Submitted: 08-11-2021 Accepted: 22-12-2021 Online: 29-01-2022

Rapid transfer of Rabies virus to the central nervous system (CNS) through the peripheral nervous system (PNS) is the important step in Rabies virus pathogenesis (Salinas et al. 2010). At the site of dog bite, after entry of virus into the infected cell, neurons (PNS), Rabies virus particles are mistaken for cargo. PNS uses trafficking components, allowing virus particles to undergo axonal transport. The virus 
uses neurotrophin transport machinery to reach the CNS. Rabies virus travels faster and is more directed when transported with p75NTR. (Gluska et al., 2014).

The aim of present study was to determine the pattern of animal bite and onset of clinical signs of the rabies in cattle, with history of dog bite above neck region (i.e., close to brain) and to discuss the significance of the observations made to prevent further losses in term of fatality in the exposed cattle.

\section{MATERIALS AND METHODS Collection of clinical samples}

Brain tissue was collected from dead animals after post mortem examination using Skull open method. From live animals, saliva was collected (at hourly interval and pooled) intermittently from clinically suspected cases. Clinical specimens were preferred from the cases showing clinical signs of rabies with detailed history of dog bite above the neck region and post bite vaccination, in cattle. A total of 58 samples were collected in a span of three years from the area around Bidar district in Karnataka and Maharashtra border area (Fig 1). Twenty samples with known history of dog bite above the neck region and post exposure vaccination were selected for the present investigation. The samples were stored at $-86^{\circ} \mathrm{C}$ until further processed.

\section{Direct fluorescent antibody test (DFAT)}

All the samples were subjected to Direct Fluorescent Antibody Test for confirmation of rabies. The test was done as per the

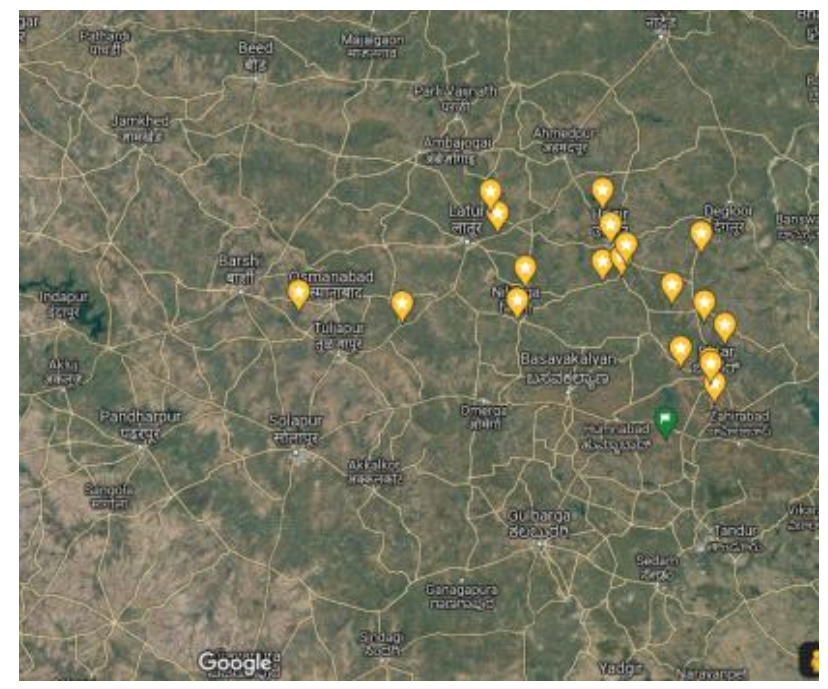

Fig 1: Map of the area depicting geographic location of the sample collection, in and around Bidar and some part of

Maharashtra, where incidences were recorded during the study period of three years 2018-2021. standard protocol given by OIE. The test was carried out at OIE Twinned Rabies Diagnostic Laboratory, Dept. of Veterinary Microbiology, Veterinary College, Hebbal, KVAFSU, Bangalore.

In brief, for each of the samples, three impressions smears were made one each for the anti-rabies nucleoprotein IgG- FITC conjugate (Millipore-Light Diagnostics, Rabies DFA III) and negative control FITC conjugate (Millipore- Light Diagnostics). The brain sample of healthy cattle was also included in the test as a negative control. Rabies CVS strain infected brain sample of mice was used as positive control. The brain impression smears on taken on slides were blotted using paper towels in order to remove excess of moisture and the blood stains. Then were initially air dried for $5 \mathrm{~min}$. before fixing in high grade chilled acetone $(80 \% \mathrm{v} / \mathrm{v})$ for an hour at $-20^{\circ} \mathrm{C}$. The fixed impressions were air dried to ensure the removal of acetone traces and stained using 1:100 dilution of the above said FITC conjugates by incubating in a humid chamber at $37^{\circ} \mathrm{C}$ for $60 \mathrm{~min}$. The impressions were washed with $1 \times$ PBS for $5 \mathrm{~min}$. and the wash step was repeated twice to remove excess stain. The stained impressions were observed under a fluorescent microscope. Presence of typical granular intra-cytoplasmic apple green fluorescence of aggregated nucleocapsid was used as a criterion in declaring positive result, whereas absence of green fluorescence as test negative for the samples. Positive and negative samples were further subjected to RT-PCR for molecular detection of rabies virus.

\section{Viral RNA extraction}

RNA extractions were performed using triturated brain samples in phosphate buffer saline, as starting material. RNA was extracted using Trizol (Life Technologies, Rockville, MD).

In brief, following, manufacturer's instructions (Chomczynski et al., 1987) with slight modifications, for RNA extraction, $0.75 \mathrm{ml}$ of Trizol reagent per $0.25 \mathrm{ml}$ of brain tissue triturated along with PBS was used. Lysate was pippeted up and down several times to homogenize and incubated for 5 minutes at room temperature. Followed by centrifugation and aqueous phase was collected. Addition of Trizol reagent again, in the same proportion was done as per the manufacturers protocol. All the sample and a control of nuclease-free water were processed to yield a total volume of $100 \mathrm{ul}$ of total RNA for each sample.

The total RNA of each sample was quantified using Nanospectrophotometer with ultraviolet light absorbance at 260 $\mathrm{nm}$. The ratio of optical density at wavelengths of $260 \mathrm{~nm}$ and $280 \mathrm{~nm}$ was used to assess the purity of the RNA.

\section{Primer used for reverse transcriptase polymerase chain reaction (RT-PCR)}

Published primer for $G$ gene of Rabies virus was used in the present study. Primer sequences used in the present study are as follows:

\begin{tabular}{lllcl}
\hline Target gene & Primer & \multicolumn{1}{c}{ Sequence } & Amplicon size (bp) & Reference \\
\hline Glycoprotein & Forward & TAA TCC CAG AGA TGC AAT CA & 406 & Gupta et al., 2005 \\
gene & Reverse & CCT CAG AGT CTG GTC TCA CC & & \\
\hline
\end{tabular}




\section{Reverse transcriptase polymerase chain reaction}

One-Step RT-PCR protocol (Superscript Platinum III one step $\mathrm{RT}-\mathrm{PCR}$ ) required $60 \mathrm{~min}$ at $50^{\circ} \mathrm{C}$ for CDNA synthesis by Reverse Transcription, followed by $4 \mathrm{~min}$ at $94^{\circ} \mathrm{C}$ for inactivation of reverse transcriptase and Taq polymerase activation, 35 cycles of $94^{\circ} \mathrm{C}$ for $45 \mathrm{~s}$, primer annealing at $53^{\circ} \mathrm{C}$ for $45 \mathrm{~s}, 72^{\circ} \mathrm{C}$ for $1 \mathrm{~min}$, followed by a final elongation at $72^{\circ} \mathrm{C}$ for $5 \mathrm{~min}$.

PCR products were visualized on a 1.5\% TAE agarose gel containing $0.5 \mathrm{ug} / \mathrm{ml}$ ethidium bromide. One-Step RTPCR protocol resulted in a $406 \mathrm{bp}$ product from the glycoprotein gene i.e., $\mathrm{G}$ gene of rabies virus.

\section{RESULTS AND DISCUSSION}

Out of 58 samples, the cases with known history of dog bite above neck region and vaccination history, 20 clinical samples subjected to direct fluorescence antibody test were found positive.

\section{Observations recorded from dog bite to onset of clinical signs of rabies}

The rabies cases under investigation were observed carefully and recorded the site of dog bite, incubation period and the onset of symptoms. The cases were treated under the supervision or by the veterinarians in village clinics and or at the farm of the handler of cattle. The anti-rabies vaccination schedule i.e., $0,3,7,14$ and 28 day was adopted and followed for all the cattle under study.

In cattle, very commonly recorded site of dog bite was at the muzzle, near nostrils, base of horn, base of ear, dorsolateral aspect of muzzle (Fig 2). Entry of virus through dog bite close to the brain, facilitates rapid entry of virus in to the brain.

In adult cattle including cow, bullock, buffalo after completion of $0,3,7$ and $14^{\text {th }}$ day post bite vaccination, onset of clinical signs were recorded on $20^{\text {th }}$ day from the day of dog bite. And within 48-72 hours after onset of clinical

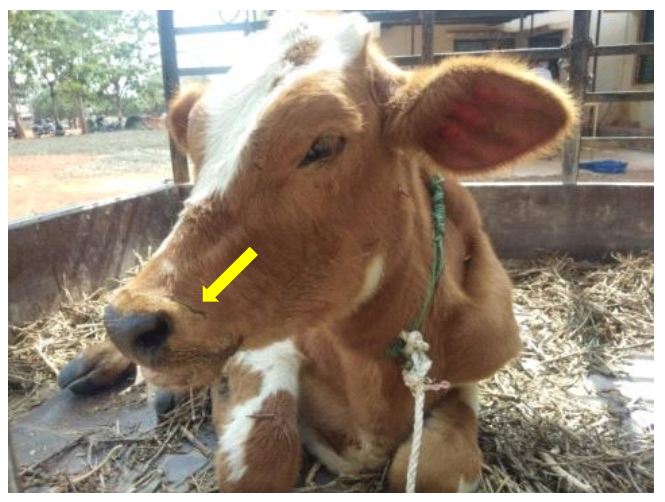

Fig 2: Site of rabid dog bite injury in Jersey calf.

Table 1. The sampling details with special reference to site of dog bite and occurrence of first clinical sign after dog bite.

\begin{tabular}{|c|c|c|c|c|c|c|c|}
\hline ID/Strain & Species & Age & Sex & Location & $\begin{array}{l}\text { Date of } \\
\text { Sample } \\
\text { collection }\end{array}$ & $\begin{array}{c}\text { Site of } \\
\text { dog bite }\end{array}$ & $\begin{array}{r}\text { Occurrence } \\
\text { of first } \\
\text { clinical sign }\end{array}$ \\
\hline BASWA K1 & Buffalo & $8 Y$ & Female & Kamthana, Bidar, Karnataka & $22-02-2019$ & Muzzle & $20^{\text {th }}$ day \\
\hline AB K2 & Buffalo & $3.5 \mathrm{M}$ & Male & Belur, Bidar, Karnataka & $18-02-2020$ & $\begin{array}{l}\text { Dorsolateral } \\
\text { aspect of muzzle }\end{array}$ & $20^{\text {th }}$ day \\
\hline AB K3 & Buffalo & $6 Y$ & Female & Bidar, Karnataka & $04-08-2020$ & Muzzle & $20^{\text {th }}$ day \\
\hline AB K4 & Bullock & $8 Y$ & Male & Khanapur, Bidar, Karnataka & $28-09-2020$ & Muzzle & $20^{\text {th }}$ day \\
\hline AB M5 & Buffalo & $6 \mathrm{Y}$ & Female & Ujani,Maharashtra & $21-10-2020$ & Ear & $20^{\text {th }}$ day \\
\hline AB M7 & Buffalo & $7 Y$ & Female & Udgir,Maharashtra & $06-11-2020$ & Muzzle & $20^{\text {th }}$ day \\
\hline AB M9 & Buffalo & $8 Y$ & Female & Belsakharga, Maharashtra & $08-11-2020$ & Muzzle & $20^{\text {th }}$ day \\
\hline AB M10 & Cow calf & $3 \mathrm{M}$ & Female & Kharola, Maharashtra & $19-11-2020$ & Base of horn & $15^{\text {th }}$ day \\
\hline AB M13 & Buffalo & $4 Y$ & Female & Bhatambra Ashta Mod, Maharashtra & $10-12-2020$ & Muzzle & $20^{\text {th }}$ day \\
\hline GL K14 & Buffalo & $18 \mathrm{M}$ & Female & Shrimandal, Bidar, Karnataka & $10-12-2020$ & Muzzle & $20^{\text {th }}$ day \\
\hline AB K15 & Bullock & $4 Y$ & Male & Ghodepalli, Bidar, Karnataka & $12-12-2020$ & $\begin{array}{l}\text { Dorsal aspect } \\
\text { of muzzle }\end{array}$ & $20^{\text {th }}$ day \\
\hline AB K16 & Buffalo & $30 \mathrm{M}$ & Female & Shrimandal, Bidar, Karnataka & $14-12-2020$ & Muzzle & $20^{\text {th }}$ day \\
\hline AB K17 & Buffalo & $20 \mathrm{M}$ & Female & Nirna,Bidar, Karnataka & $18-12-2020$ & Muzzle & $20^{\text {th }}$ day \\
\hline AB M18 & Buffalo & $8 Y$ & Female & Shirol, Nilanga, Maharashtra & 01-01-2021 & Muzzle & $20^{\text {th }}$ day \\
\hline AB M19 & Buffalo & $5 Y$ & Female & Nitur, Nilanga Maharashtra & 05-01-2021 & Muzzle & $20^{\text {th }}$ day \\
\hline AB K20 & $\begin{array}{c}\text { Cow Heifer } \\
\text { Jersey }\end{array}$ & $1 \mathrm{Y}$ & Female & Hippalgaon, Karnataka & $14-01-2021$ & $\begin{array}{l}\text { Dorsolateral } \\
\text { region of muzzle }\end{array}$ & $15^{\text {th }}$ day \\
\hline SPY M21 & Cow calf & $2 \mathrm{M}$ & Male & Gurnal, Deoni,Maharashtra & $15-01-2021$ & Muzzle & $15^{\text {th }}$ day \\
\hline AB K23 & Bullock & $7 Y$ & Male & Karvat & $27-01-2021$ & Base of horn & $20^{\text {th }}$ day \\
\hline AB M26 & Buffalo & $5 Y$ & Female & Jamb, Maharashtra & 09-03-2021 & Muzzle & $20^{\text {th }}$ day \\
\hline AB M38 & Buffalo & $6 \mathrm{M}$ & Female & Kudali, Hanegaon, Maharashtra & 23-04-2021 & Base of left horn & $20^{\text {th }}$ day \\
\hline
\end{tabular}

Y- Year; M- Month. 
signs (as detailed below), death of animal was recorded Table1.

In calves under study, after completing of 0,3 and 7 days post bite vaccination schedule, onset of clinical signs were recorded i.e., on $15^{\text {th }}$ day from the day of dog bite, was reported by the farmers. And within 48-72 hours after onset of clinical signs, death of animal was recorded.

Similar findings were recorded by Hudson et al., 1996, Lojkï̈ et al., 2013. In experimentally infected cattle, the average incubation period recorded by Hudson et al., 1996 was 15.1 days and the average morbidity period was 3.7 days. Of those, the naive cattle had significantly shorter incubation and morbidity periods than the test-vaccinated cattle.

The incubation period of rabies depends on the location and severity of the wound and the amount of virus introduced and is highly variable in a wide range of host species. For cattle, it varies from 20 to 165 days (Hudson et al., 1996), but in this present study, the dog bite above the neck region was considered, in which 15 days in calves and 20 days incubation period in case of adult cattle was recorded. These findings are in concurrence with findings of Hudson et al., but the incubation period in calves recorded in this study differs, i.e., 15 days.

\section{Clinical signs recorded in cattle}

The first clinical sign observed was anorexia (100\%), hyperaesthesia, behavioural change followed by increase in aggressiveness (90\%), micturition (70\%), head pressing or hitting inanimate objects $(70 \%)$, bellowing $(60 \%)$, salivation $(90 \%)$ were the prominent and common signs seen. Bellowing was very commonly seen in buffaloes $(100 \%)$.

The most obvious symptoms recorded by Barnard et al., 1979, were salivation (92\%), bellowing (69\%), aggressiveness $(47 \%)$, paresis or paralysis $(30 \%)$ and straining (12\%). Common clinical signs included excessive salivation $(100 \%)$, behavioural change $(100 \%)$, muzzle tremors $(80 \%)$, vocalization (bellowing; $70 \%$ ), aggression, hyperaesthesia and/or hyper excitability (70\%) and pharyngeal paresis/paralysis $(60 \%)$. The furious form of rabies was seen in $70 \%$ of the cattle was recorded by Hudson et al., 1996. The present study findings were in accordance with the findings of Barnard et al., 1979, Hudson et al. 1996, except the bellowing was observed very commonly in 100 per cent buffaloes.

\section{Direct Florescent Antibody test (DFA)}

All the 20 clinical samples subjected to Direct fluorescent Antibody test were found positive for rabies virus (Fig 3).

The use of fluorescent antibodies for diagnosing rabies as the standard and reliable test was placed on record by Asil'eva et al., 1967; Nikolaenko et al., 1967; Tarabrina et al., 1968; Prabhu et al., 2018 and recommended by OIE. The present study findings are in concurrence with findings mentioned above. But in DFAT weakly positive fluorescence results in 03 samples were attributed to improper storage of the brain tissue, due to purification of the lipid rich brain tissue might have resulted into weakly positive results with pale background instead of reddish background (DFAT using $0.0125 \%$ Evan's blue) with direct fluorescent test, which was further confirmed by Reverse Transcriptase Polymerase chain reaction.

\section{Amplification of $\mathbf{G}$ gene of rabies virus by RT-PCR}

The application of Reverse Transcriptase Polymerase chain reaction to the samples under study amplified glycoprotein gene i.e., G gene, the product size was 406 base pairs (Fig 4). The amplified product was sequenced and BLAST was done using NCBI gene bank. The sequences revealed 99 per cent identity.

Reverse transcriptase polymerase chain reaction amplification of Glycoprotein gene was used as a molecular diagnostic tool for detection of Rabies Lyssavirus and to study the variation in amino acid sequence of glycoprotein genes by Gupta et al., (2005), Pharande et al., (2021). Similar findings were recorded in the present study.

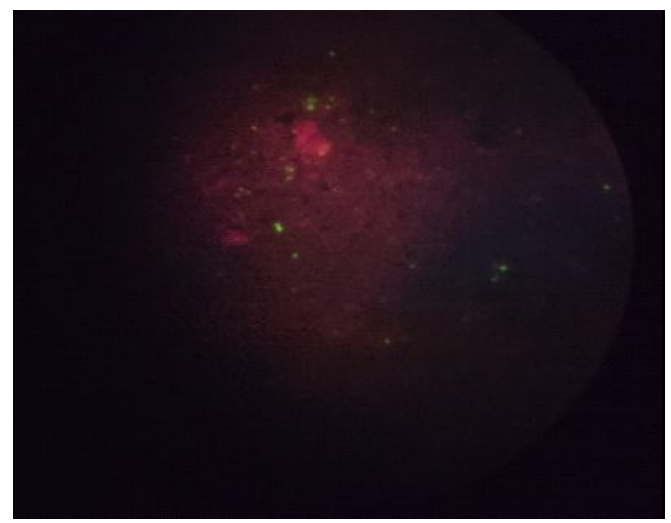

Fig 3: Direct Florescent Antibody test (DFA) showing fluorescence of rabies virus inclusions Magnification 40X.

\section{L1 L2 L3 L4 L5 $\quad$ M N}

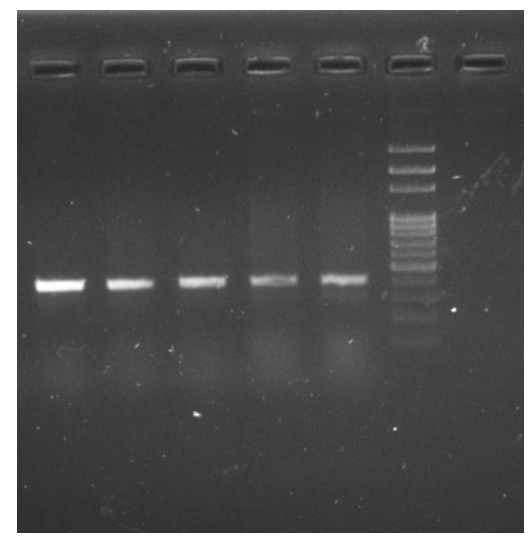

Fig 4: Amplification of $\mathrm{G}$ gene of rabies virus by RT-PCR, 406 base pair amplicon size and. Lane 12,3,4 - Clinical Samples, Lane 5- Known standard CVS strain of Rabies virus, M-100 base pair marker and $\mathrm{N}$-Negative control. 
Most of rabies deaths occur among those who delayed, did not receive, or complete rabies PEP. Important observation to put on record is that the dog bite above the neck region in cattle, even after giving the post exposure vaccination, turned to be fatal.

The neutralizing antibody test using serum, after post bite immunization in domestic camels and cattle revealed the cut-off value of rabies RVNA titre as $0.50 \mathrm{IU} / \mathrm{mL}$, is defined as the minimum antibody level affording complete protection (Liu et al., 2016).

Use of Rabies antisera, is the recommendations given by OIE and WHO for the post exposure prophylaxis in exposed animals, is generally not practised in the treatment of large ruminants or bovines. Being, economically not viable, the dose of immune sera recommended. Use of antisera at least at the local site of dog bite injury immediately after dog bite reduces the fatality to a great extent.

Further investigation requires the detailed study on antibody titres in post bite cases of rabies in relation to the present post bite vaccination schedule in cattle and the efficacy especially in bites above the neck region, where the incubation period is very short ranging from 15 days to 20 days. The study should also include the use of Anti-rabies serum at the dog bite site along with recommended antirabies post exposure regime.

\section{CONCLUSION}

The occurrence of clinical signs was seen in cattle undergoing the post bite vaccination. Fatality rate recorded was 100 per cent in case of cattle with site of dog bite above the neck especially at the muzzle and base of the neck, despite of having treated with post bite anti-rabies vaccine alone, without use of rabies antisera as a passive way of treating successfully in such cases. Rabies post bite vaccination is not protective, if the site of dog bite is above the neck region i.e., muzzle, base of horn, ear, dorso-lateral aspect of muzzle in cattle. Further study with antibody titre assessment of naturally infected cattle, immediately after dog bite and after post bite shots, antibody titres should be pursued.

The treatment of dog bite cases in large ruminants should include the recommendations given by OIE and WHO regarding the use of Rabies antisera at the site of dog bite, if the dog bite is close to brain i.e., above the neck region can save the large population of exposed animals.

\section{Conflict of interest}

The authors declare that they have no conflict of interests.

\section{Ethical Issues}

Ethical clearance was obtained from the institutional ethical committee. Permission to carry out the study was granted by following the set guidelines by OIE and WHO for handling infected material of rabies suspected and confirmed cases.

\section{ACKNOWLEDGEMENT}

I would like to thank Dr. Srikrishna Isloor, Incharge, OIE Twinned Rabies Diagnostic Reference Laboratory, Dept. of
Veterinary Microbiology, Veterinary College, Hebbal, KVAFSU, Bangalore for his assistance in identifying specimens and making available to us facilities for rabies diagnosis and guidance.

\section{REFERENCES}

Alvarez, L., Fajardo, R., Lopez, E. (1994). Partial recovery from rabies in a nine-year-old boy. Pediatric Infectious Disease Journal. 13: 1154-1155.

Asil'eva, E.F., Mokrousova, A.V., Titlova, Z.I. (1967). Primenenie fluorestsiruiushchikh antitel dli diagnostiki behenstva [The use of fluorescent antibodies for diagnosing rabies]. Veterinariia. 44(8): 45-6.

Barnard, B.J. (1979). Simptome van hondsdolheid by huis- en plaasdiere in suid-afrika en suidwes-afrika [Symptoms of rabies in pets and domestic animals in South Africa and South West Africa (author's transl)]. Journal of South African Veterinarian Association. 50(2):109-11.

Bedeković,T., Lohman, J.I., Šimić, I., Krešić, N., Lojkić, I., Suèec, I. (2018) Control and elimination of rabies in Croatia. PLoS ONE. 13(9): e0204115.

Chomczynski, P. and Sacchi, N. (1987). Single Step Method of RNA Isolation by Acid Guanidinium Thiocyanate-PhenolChloroform Extraction. Analytical Biochemistry.162: 156-159.

Gill, G.S., Singh, B.B., Dhand, N.K, Aulakh, R.S., Sandhu, B.S., Ward, M.P. (2019). Estimation of the incidence of animal rabies in Punjab, India. PLoS ONE. 14(9): e0222198.

Gluska, S., Zahavi, E.E., Chein, M., Gradus, T., Bauer, A. (2014). Rabies Virus Hijacks and Accelerates the p75NTR Retrograde Axonal Transport Machinery. PLoS Pathogens. 10(8): e1004348.

Gupta, P. K., V. K. Chaturvedi, P. C. Verma and K. D. Pandey (2005). Differentiation of Rabies Fixed and Street Viruses Using RT-PCR Coupled with Restriction Endonuclease Analysis. Indian Journal of Biotech. 4: 284-286.

Hampson, K., Coudeville, L., Lembo, T., Sambo, M., Kieffer, A., Attlan, M. (2015). Estimating the global burden of endemic canine rabies. PLoS Neglected Tropical Diseases. 9(4): e0003709.

Hattwick, M.A., Weis, T.T., Stechschulte, C.J., Baer, G.M., Gregg, M.B. (1972). Recovery from rabies. A case report. Annals of Internal Medicine. 76: 931-942.

Hudson, L.C., weinstock, D., jordan, T. and Bold-fletcher, N.O. (1996). Clinical features of experimentally induced rabies in cattle and sheep. Journal of Veterinary Medicine. 43: 85-95.

Jackson, A.C., Wunner, W.H. (2007). Rabies. $2^{\text {nd }}$ edn. San Diego, Academic press.69

Liu, Y., Zhang, H.P., Zhang, S.F., Wang, J.X., Zhou, H.N., Zhang, F. (2016). Rabies outbreaks and vaccination in domestic camels and cattle in Northwest China. PLoS Neglected Tropical Diseases. 10(9): e0004890.

LojkiÄ, I., BedekoviÄ, T., ÄOEaÄ, Å., Lemo, N., CvetniÄ, Å. (2013). Clinical rabies in cattle imported into Croatia. The Veterinary Record. 172(1): 22.

Madhusudana, S.N., Nagaraj, D., Uday, M., Ratnavalli, E., Kumar, M.V. (2002). Partial recovery from rabies in a six-yearold girl. International Journal of Infectious Diseases. 6: 8586 . 
Occurrence of Rabies in Post Exposure Vaccinated Cattle with Dog Bite Injury above the Neck Region

Mahadevan, A., Suja, M.S., Mani, R.S. and Shankar, S.K. (2016). Perspectives in Diagnosis and Treatment of Rabies Viral Encephalitis: Insights from Pathogenesis. Neurotherapeutics: The Journal of the American Society for Experimental NeuroTherapeutics.13(3): 477-492.

Nikolaenko, I.G. (1967). Metod fluorestsiruiushchikh antitel pri diagnostike beshenstva [The fluorescent antibody technic in the diagnosis of rabies]. Veterinariia. 44(7): 42-3.

Pharande, R.R., Majee, S.B., Gaikwad, S.S., Moregoankar, S.D., Bannalikar, A., Doiphode, A., Gandge, R., Dighe, D., Ingle, S,, Mukherjee, S. (2021). Evolutionary analysis of rabies virus using the partial Nucleoprotein and Glycoprotein gene in Mumbai region of India. Journal of General Virology. 102(3). DOI: 10.1099/jgv.0.001521.

Porras, C., Barboza, J.J., Fuenzalida, E., Adaros, H.L., Oviedo, A.M., Furst, J. (1976). Recovery from rabies in man. Annals of Internal Medicine. 85: 44-48.

Prabhu, K.N., Isloor, S., Veeresh, B.H., Rathnamma, D., Sharada, R., Das, L.J., Satyanarayana, M.L., Hegde, N.R.,
Rahman, S.A. (2018). Application and comparative evaluation of fluorescent antibody, immunohistochemistry and reverse transcription polymerase chain reaction tests for the detection of rabies virus antigen or nucleic acid in brain samples of animals suspected of rabies in India. Veterinary Sciences. 5(1): 24.

Salinas, S., Schiavo, G., Kremer, E.J. (2010). A hitchhiker's guide to the nervous system: the complex journey of viruses and toxins. Nature Reviews Microbiology. 8: 645-655.

Tarabrina, A.P. (1968). Diagnostika beshenstva s pomoshch'iu fluorestsiruiushchikh antiel $i$ bioproby [Diagnosis of rabies with the use of fluorescent antibodies and biological samples]. Veterinariia. 45(6):99-100.

WHO (2018). Expert Consultation on Rabies, third report. WHO Technical Series Report No. 1012. Geneva. ISBN 97892-4-121021-8.

Willoughby, R.E., Rotar, M.M., Dohnau, H.L., (2004). Recovery of a patient from clinical rabies-Wisconsin. MMWR MorbMortal Weekly Report. 53: 1171-1173. 